\title{
Analisis Sentimen Pilkada di Tengah Pandemi Covid-19 Menggunakan Convolution Neural Network (CNN)
}

\author{
Sukma Nindi Listyarini" ${ }^{*}$, Dimas Aryo Anggoro² \\ ${ }^{1,2}$ Informatika, Fakultas Komunikasi dan Informatika, Universitas Muhammadiyah Surakarta, Indonesia \\ Email: ${ }^{1}$ sukmanindi30@gmail.com, ${ }^{2}$ Dimas.a.anggoro@ums.ac.id
}

\begin{abstract}
Abstrak
Pemilihan kepala daerah 2020 menjadi kontroversi, sebab dilaksanakan ditengah pandemi covid-19. Komentar muncul di berbagai lini media sosial seperti twitter. Banyak masyarakat yang setuju pilkada dilanjutkan, namun banyak juga yang perpendapat untuk menunda pilkada sampai masa pandemi berakhir. Melihat perbedaan pendapat seperti ini, perlu dilakukan analisis sentimen, dengan tujuan untuk memperoleh persepsi atau gambaran umum masyarakat terhadap penyelenggaraan pilkada 2020 saat pandemi covid-19. Sebanyak 500 tweet diperoleh dengan cara crawling data dari twitter API menggunakan library tweepy, bedasarkan keyword yang telah ditentukan. Dataset yang didapat diberi label ke dalam dua kelas, negatif dan positif. Penelitian ini mengusulkan pendekatan deep learning dengan algoritma Convolution Neural Network (CNN) untuk klasifikasi, yang terbukti efektif untuk tugas Natural Language Processing (NLP) dan mampu mencapai kinerja yang baik dalam klasifikasi kalimat. Percobaan dilakukan dengan menerapkan 4-layer convolutional dan mengamati pengaruh jumlah epoch terhadap akurasi model. Variasi epoch yang digunakan adalah 50, 75, 100. Hasil dari penelitian menunjukkan bahwa, metode CNN dengan dataset pilkada ditengah pandemi mendapatkan akurasi tertinggi sebesar 90\% dengan 4-layer convolutional dan 100 epoch. Didapatkan pula bahwa, semakin banyak epoch yang digunakan dalam model, akurasi cenderung meningkat.
\end{abstract}

Kata kunci: analisis sentimen, covid-19. cnn, deep learning, NLP

\section{Sentiment Analysis Regional Elections During Pandemic Covid-19 Using Convolution Neural Network (CNN)}

\begin{abstract}
The 2020 regional head election is controversial, because it was held during the Covid-19 pandemic which was endemic in Indonesia. Comments appear on various social media such as twitter. Many people agree that the elections will be continued, but there are also many who think that they should postpone the elections until the pandemic period ends. Seeing differences of opinion like this, it is necessary to carry out sentiment classification or sentiment analysis, with the aim of obtaining public perceptions or public opinions of the 2020 regional elections during the Covid-19 pandemic. Total 500 tweets were obtained by crawling data from the twitter API using the tweepy library, based on predetermined keywords.. The data sets obtained were labeled into two classes, negative and positive. This study developed a deep learning approach with the Convolution Neural Network (CNN) algorithm for classification, proven to be effective for Natural language processing (NLP) tasks and able to achieve good performance in sentence classification. The experiment was implement by applying 4 convolutional layers and observe the effect of total epochs on the model accuracy. The epoch variations used are 50, 75, 100.. The results showed that the CNN method with the local election dataset in the middle of the pandemic received the highest accuracy of $90 \%$ with 4-layers convolutional and 100 epoch. It was also found that, the more epochs used in the model, the accuracy tends to increase.
\end{abstract}

Keywords: covid-19, cnn, deep learning, NLP, sentiment analysis

\section{PENDAHULUAN}

Pelaksanaan pilkada atau pemilihan kepala daerah 2020 menjadi kontroversi, sebab dilaksanakan dimasa pandemi covid-19 yang melanda Indonesia. Dimana Kementrian Kesehatan telah mengeluarkan peraturan pemberlakuan PSBB (pembatasan sosial berskala besar) di seluruh Indonesia [1]. Meskipun demikian, KPU tetap menjadwalkan ulang pelaksanaan pilkada hingga akhir tahun 2020. KPU yakin dengan peraturan KPU 
no.13 tahun 2020, pilkada 2020 akan tetap dilaksanakan dengan mengutamakan protokol kesehatan pada setiap tahapan pilkada.

Menanggapi dua kondisi yang sama pentingnya, komentar muncul diberbagai lini media sosial seperti twitter. Kekhawatiran netizen (citizen of the net) muncul apabila pilkada serentak 2020 tetap dilaksanakan, kemungkinan covid-19 semakin tidak dapat dikendalikan. Pilkada ini akan menjadi ajang penyebaran dan penularan covid-19 secara besar-besaran. Bagaimanapun juga, tidak dapat diperkirakan kapan berakhirnya pandemi covid-19, sedangkan pesta demokrasi pilkada juga penting dilaksanakan untuk merangsang pembangunan dan kesejahteraan bagi masyarakat daerah [2].

Melihat kondisi seperti ini, perlu dilakukan suatu analisis sentimen atau dikenal juga sebagai opinion mining[3]. Analisis sentiment dilakukan dengan tujuan untuk memperoleh persepsi atau gambaran umum masyarakat terhadap penyelenggaraan pilkada di masa pandemi covid. Apakah masyarakat setuju dengan pelaksanaan pilkada (sentimen positif) atau tidak setuju dilaksanakannya pilkada 2020 (sentimen negatif). Sehingga hasil analisis dapat dijadikan landasan bagi pemerintah untuk mengambil keputusan terkait pelaksanaan pikada.

Analisis sentimen merupakan proses mengekstraksi dan mengidentifikasi opini atau informasi subjektif pada sebuah teks. Analisis sentimen dapat menentukan sikap penulis terhadap suatu entitas, apakah positif, negatif atau netral [4]. Analisis sentimen melibatkan komputasi dalam memahami sentimen tersirat di dalam sebuah teks. Natural language processing (NLP) dikenal sebagai komputasi linguistik yang mampu menyelesaikan masalah praktis dalam memahami bahasa manusia [5]. NLP memungkinkan mesin memproses dan menerjemahkan bahasa alami manusia ke dalam format yang dapat dimengerti oleh mesin[6]. Penelitian oleh Cui dkk [7] membuktikan bahwa penerapan algoritma Convolution Neural Network (CNN) efektif untuk tugas NLP dan mampu mencapai kinerja yang baik dalam klasifikasi kalimat.

Banyak penelitian mengangkat tema analisis sentimen menggunakan NLP dan penerapan algoritma CNN sebagai klasifikasi. Penelitian yang dilakukan oleh Guan dkk [8] mengusulkan gabungan antara Weaklysupervised Deep Embedding (WDE) dan CNN untuk klasifikasi sentimen tingkat kalimat. Penelitian Poria dkk [9] membangun model CNN untuk mendeteksi sarkastik pada twitter. Penelitian oleh Rhanoui dkk [10] menjelaskan bahwa model CNN sangat kuat dalam ekstraksi fitur dan cocok untuk analisis opini artikel panjang. Penelitian lain oleh Rehman dkk [4] menjelaskan bahwa model CNN yang menggunakan convolutional layer dan max pooling layer secara efisien dapat mengekstrak fitur lebih tinggi.

Bedasarkan studi literatur yang telah dilakukan, masih sedikit yang meneliti pengaruh banyaknya layer convolutional dan banyaknya epoch yang diterapkan di dalam model CNN. Epoch merupakan step dalam proses training $\mathrm{CNN}$, dimana seluruh dataset telah melewati forward dan backward propragation dalam satu kali putaran [11]. Epoch kecil dapat menghasilkan kinerja yang buruk karena penyesuaian parameter yang tidak lengkap, sementara epoch besar mungkin meningkatkan waktu komputasi serta risiko overfitting [12].

Untuk itu, penelitian ini mengusulkan melakukan analisis sentimen pilkada ditengah pandemi covid-19 menggunakan teknik NLP untuk mengolah dan mengekstrak data dari twitter. Hasil preprocessing berupa tokentoken kata selanjutnya diklasifikasikan dengan pendekatan deep learning menggunakan algoritma Convolution Neural Network (CNN). Algoritma CNN dipilih karena memiliki kemampuan ekstraksi fitur yang tinggi. Hasil penelitian ini berupa perbandingan akurasi dari penerapan 4-layer konvolusi dan pengaruh banyaknya epoch yang digunakan dalam model, serta hasil label prediksi pada uji kemampuan terhadap input kalimat baru.

\section{METODE PENELITIAN}

Persoalan utama dalam klasifikasi sentimen adalah cara mengidentifikasi sentimen dalam sebuah teks, apakah teks memiliki sentimen positif atau negatif. Gambar 1 merupakan alur yang diterapkan pada penelitian ini [13]. Langkah pertama, pengambilan data atau crawling data dari twitter, selanjutnya seluruh data diberi label ke dalam dua kelas, positif dan negatif. Langkah selanjutnya preprocessing menggunakan teknik NLP. Hasil dari preprocessing berupa token-token akan menjadi input pada proses klasifikasi. Proses klasifikasi menggunakan pendekatan deep learning dengan algoritma Convolution Neural Network (CNN).

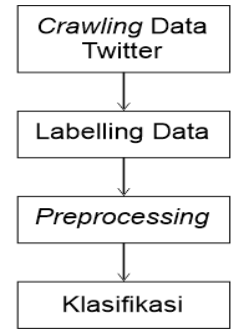

Gambar 1. Langkah Penelitian 


\subsection{Crawling Data}

Data diambil dari twitter menggunakan bahasa pemrograman Python, dengan library tweepy untuk menghubungkan ke Twitter API. Sebanyak 500 tweet dipilih dengan kata kunci penelusuran diantaranya "pilkada", "pemilu", "corona", "pandemi" dan "covid-19". Contoh hasil crawling data twitter ditunjukkan pada tabel 1, tweet tersebut dipilih secara acak, merujuk pada kondisi pilkada di masa pandemi covid-19.

Tabel 1. Contoh Hasil Crawling Data Twitter

\begin{tabular}{|c|c|}
\hline Tanggal & Tweet \\
\hline 2020-10-11 & $\begin{array}{l}\text { RT C nusinumar: Udah lah gak usah paksakan Pilkada, ini tuh bahaya } \\
\text { banget bisa" muncul cluster baru https://t.co/SbeiPhnLGJa.. }\end{array}$ \\
\hline 2020-10-11 & $\begin{array}{l}\text { RT @ Nuuasuina: 18) Pandemi tak bisa dijadikan alasan untuk menunda } \\
\text { hajatan lima tahunan yang sudah berjalan dan diagendakan lama. } \\
\text { https://t... }\end{array}$ \\
\hline $2020-10-15$ & $\begin{array}{l}\text { RT Eviusiastuti: Masyarakat antusias dan optimis Pilkada berjalan } \\
\text { lancar. Sosialisasi melaksanakan disiplin protokol kesehatan ketat }\end{array}$ \\
\hline $2020-11-26$ & $\begin{array}{l}\text { Patuhi protokol kesehatan saat pilkada stop penyebaran virus corona } \\
\text { https://t.co/0uCZE6i5Oh }\end{array}$ \\
\hline 2020-10-11 & $\begin{array}{l}\text { Ntar pilkada jangan datang, biar aja mereka yang datang ke rumah. } \\
\text { Alasannya covid aja kan namanya juga perwakilan } \backslash \text { n\#Pilkada2020 }\end{array}$ \\
\hline
\end{tabular}

\subsection{Labelling Data}

Pemberian label pada dataset dilakukan secara manual dengan bantuan pakar. Data diberi label positif dan negatif. Dari hasil labelling didapatkan sebanyak 250 tweet sentimen negatif dan 250 tweet dengan sentimen positif.

\subsection{Pre-processing}

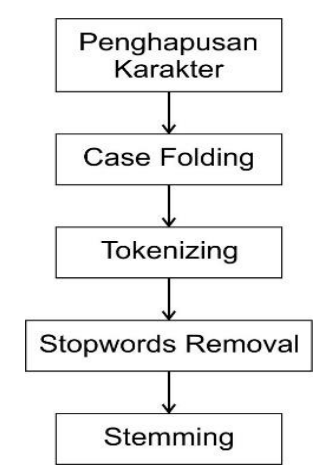

Gambar 2. Langkah Preprocessing

Data yang diperoleh dari twitter umumnya berupa kalimat yang tidak terstruktur contoh pada tabel 1, seperti terdapat karakter non alfanumerik, link url, tata bahasa tidak teratur, dll. Adanya noise dan ketidakteraturan data memengaruhi kinerja mesin [14]. Preprocessing NLP adalah langkah penghapusan noise yang tidak diinginkan dari dataset twitter [15], sehingga data yang dihasilkan menjadi lebih terstruktur. Penelitian oleh [16] mempelajari dampak preprocessing pada analisis sentimen, hasilnya terbukti bahwa proses preprocessing membantu dalam meningkatkan kinerja klasifikasi. Langkah preprocessing [17] ditunjukkan pada gambar 2 .

\subsubsection{Penghapusan Karakter}

Dataset yang telah diberi label selanjutnya dibersihkan dari karakter yang tidak relevan seperti link url, hastag, username, tanda baca dan karakter non alfanumerik (kecuali spasi) seperti ! @ \# \$ \& \% dll. Karakter tersebut sebagian besar dapat memengaruhi akurasi proses analisis, karena bukan termasuk teks yang dapat ditemukan di kamus [18]. Penghapusan karakter menggunakan library regular expression milik python.

\subsubsection{Case Folding}

Proses menyamaratakan seluruh kata, dengan mengkonversi huruf kapital di dataset menjadi huruf kecil [19]. 


\subsubsection{Tokenization}

Suatu proses pemotongan atau penguraian teks menjadi per kata. Hasil dari proses ini disebut token [20]. Sebagai contoh proses tokenisasi kalimat terdapat pada tabel 2.

Tabel 2. Proses Tokenisasi

\begin{tabular}{ll}
\hline Teks Asli & ayo pilkada jangan takut corona \\
\hline & 1. 'ayo', \\
Setelah Tokenisasi & 2. 'pilkada', \\
& 3. 'jangan', \\
& 4. 'takut', \\
& 5. 'corona', \\
\hline
\end{tabular}

\subsubsection{Stopwords Removal}

Penerapan stopword bertujuan untuk menghapus kata-kata yang dianggap tidak mempunyai arti penting, yang kemungkinkan berpengaruh terhadap kecepatan dan kinerja proses analisis [21]. Proses stopwords dalam penelitian ini menggunakan library python sastrawi. Beberapa kata pada stoplist python sastrawi adalah 'yang', 'untuk', 'pada', 'dan', 'ke', 'dari', dll.

\subsubsection{Stemming}

Merupakan langkah menghilangkan imbuhan berupa awalan, akhiran maupun campuran (awalan-akhiran) menjadi bentuk kata dasar sesuai kaidah bahasa Indonesia [22]. Proses stemming ini menggunakan library python sastrawi, sebuah library sederhana yang didesain untuk memperoleh kata dasar bahasa Indonesia dengan mudah. Pada tabel 3 terdapat contoh proses stemming pada kata berimbuhan.

Tabel 3. Contoh Proses Stemming

\begin{tabular}{lc}
\hline \multicolumn{1}{c}{ Sebelum di Stemming } & Sesudah di Stemming \\
\hline 1. Mengatur & Atur \\
2. Diatur & \\
3. Teratur & \\
1. Bayangkan & Bayang \\
2. Membayangkan & \\
3. Bayangan & Kerumun \\
1. Berkerumun & \\
2. Kerumunan & \\
\hline
\end{tabular}

\subsection{Klasifikasi}

Setelah melewati tahap Preprocessing dari NLP, selanjutnya data diklasifikasikan dengan pendekatan deep learning menggunakan algoritma Convolutional Neural Networks. CNN merupakan bagian dari Artificial Neural Network (ANN) yang mampu mendeteksi informasi dengan akurasi tinggi [10]. Model CNN telah memecahkan permasalahan dalam pemrosesan gambar dan saat ini peneliti-peneliti telah mengembangkan CNN untuk NLP seperti analisis sentimen, klasifikasi polaritas emosional, text summary, dll [23].

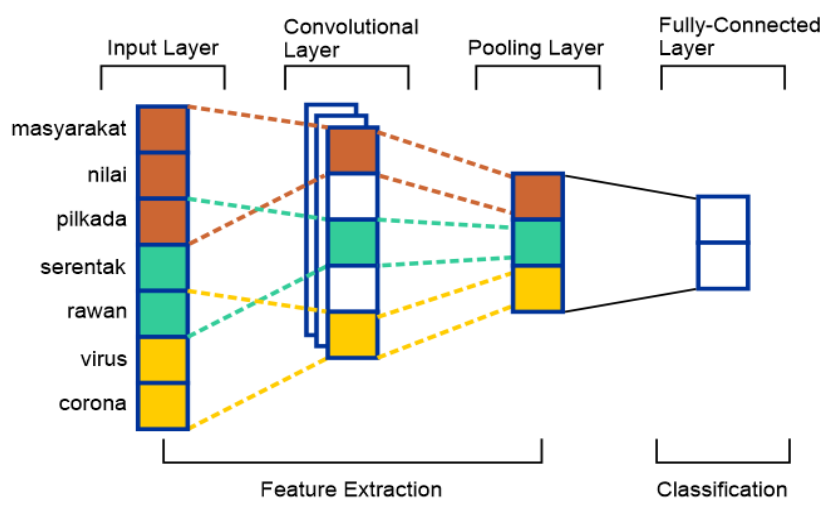

Gambar 3. Arsitektur CNN 
CNN merupakan jaringan multilayer atau biasa disebut fully-connected layer, oleh karena itu output dari satu layer akan menjadi input dari layer berikutnya. Umumnya terdiri dari layer input, hidden layer dan layer output[10]. Penelitian ini menggunakan CNN sederhana seperti gambar 3 yang dijelaskan oleh Pambudi dan Suprapto[24] pada panelitiannya, yang terdiri dari convolutional layer, max pooling layer, dropout layer dan fully connected output layer.

Pengaturan parameter dalam penelitian ini diterapkan sebanyak 300 vector size, 8 unit convolutional tiap layer dengan filter 16, 32, 64. Optimizer yang dipilih Adam [25] yang dianggap sebagai optimasi terbaik [26] dan aktivasi Rectified Linear Unit (ReLU) sebagai aktivasi non linier yang memiliki keuntungan kompleksitas rendah [17].

\section{HASIL DAN PEMBAHASAN}

Sebanyak 500 dataset twitter digunakan dalam penelitian ini. Data tersebut dikelompokkan dalam dua kategori sentimen, 0 dengan sentimen negatif dan 1 dengan sentimen positif. Pada tahapan preprocessing, dataset dibersihkan dari kebisingan, selanjutnya melalui proses tokenisasi dari 500 tweet dipecah menjadi 1.806 kata atau token. Pada proses stopwords, kata-kata yang dianggap tidak memiliki arti penting, yang terdapat pada stoplist Sastrawi dihapus. Jumlah kata berkurang menjadi 1.352 kata. Tabel 4 menunjukkan contoh dataset sebelum dan sesudah preprocessing.

Tabel 4. Contoh Proses Preprocessing

\begin{tabular}{ccc} 
Sentimen & Sebelum Preprocessing & Sesudah Preprocessing \\
\hline $\mathbf{1}$ & Patuhi protokol kesehatan saat pilkada stop & patuh protokol sehat pilkada stop sebar \\
$\mathbf{0}$ & penyebaran virus corona https://t.co/OuCZE6i5Oh'\} & virus corona \\
$\mathbf{1}$ & Corona itu bahaya, lebih baik pilkada ditunda saja! & corona bahaya lebih baik pilkada tunda \\
\hline
\end{tabular}

Kumpulan kata/token hasil preprocessing selanjutnya dijadikan input untuk proses klasifikasi. Klasifikasi pada penelitian ini mengusulkan algoritma CNN untuk membangun model dengan akurasi yang tinggi, dengan mengamati pengaruh kedalaman layer konvolusi dan pengaruh banyaknya epoch yang digunakan. Dataset penelitian dibagi menjadi tiga bagian, $70 \%$ data training, $20 \%$ data validation dan $10 \%$ data testing [27]. Pengamatan dilakukan pada 4-layer konvolusi dengan variasi epoch 50, 75, 100.

\begin{tabular}{ccccc} 
Tabel 5. Komparasi Akurasi 4-Layer Konvolusi Pada Epoch yang Berbeda \\
\cline { 3 - 5 } & & Epoch 50 & Epoch 75 & Epoch \\
& & & $\mathbf{1 0 0}$ \\
\hline \multirow{2}{*}{ Layer 1 } & Accuracy & $74 \%$ & $78 \%$ & $82 \%$ \\
& Loss & 1.0542 & 0.7871 & 0.6157 \\
Layer 2 & Accuracy & $78 \%$ & $80 \%$ & $84 \%$ \\
& Loss & 0.6790 & 0.8444 & 1.1142 \\
Layer 3 & Accuracy & $78 \%$ & $82 \%$ & $86 \%$ \\
& Loss & 1.0848 & 1.0974 & 0.7902 \\
Layer 4 & Accuracy & $82 \%$ & $86 \%$ & $\mathbf{9 0 \%}$ \\
& Loss & 1.3596 & 1.2395 & 0.7744 \\
\hline
\end{tabular}

Tabel 5 menunjukkan hasil pengujian, akurasi tertinggi sebesar 90\%, loss 0.7744 pada 4-layer konvolusi dengan 100 epoch. Bedasarkan tabel 5, seiring dengan peningkatan jumlah layer, akurasi yang didapatkan mengalami kenaikan. Peningkatan akurasi berkisar 2-4\% dari akurasi layer sebelumnnya. Meskipun, pada 2layer dan 3-layer dengan epoch 50 memiliki akurasi yang sama, namun loss validation 2-layer lebih kecil daripada 3-layer.

Selanjutnya, penelitian ini mengamati pengaruh jumlah epoch yang diterapkan pada model. Gambar 4 menunjukkan grafik hasil akurasi dari variasi epoch yang diterapkan. Pada 1-layer konvolusi hasil akurasi sebesar 74\%, 78\%, 82\%, pada 2-layer konvolusi hasil akurasi 78\%, 80\%, 84\%, sampai 4-layer konvolusi hasil akurasi $82 \%, 86 \%, 90 \%$. 


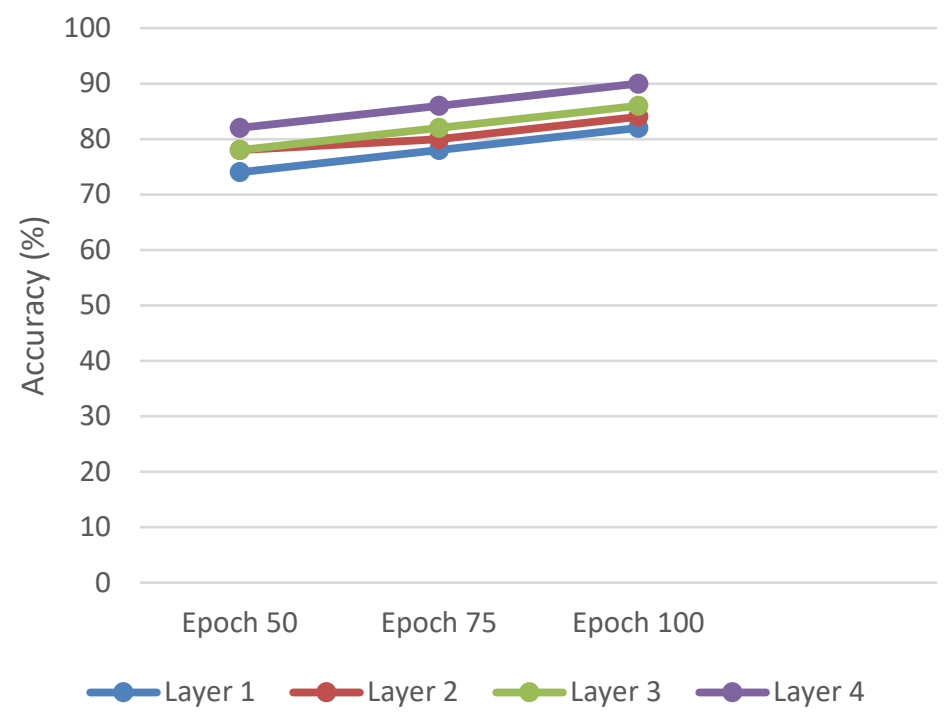

Gambar 4. Pengaruh Epoch Pada Grafik Akurasi

Bedasarkan gambar 4, terbukti bahwa akurasi empat layer meningkat seiring bertambahnya epoch. Dari epoch 50, 75 sampai 100 mengalami kenaikan akurasi berkisar antara 2-4 \% dari variasi epoch sebelumnya. Penerapan epoch yang berbeda pada proses training akan menghasilkan kemampuan klasifikasi yang berbeda. Pada epoch kecil, proses penyesuaian parameter masih belum selesai karena terbatas waktu iterasi, sehingga menghasilkan akurasi yang relatif rendah. Dengan peningkatan jumlah epoch, parameter dioptimalkan lebih lanjut, sehingga kinerja klasifikasi mengalami peningkatan secara bertahap [12].

Pengamatan selanjutnya yaitu uji klasifikasi pada kalimat baru yang tidak ada di dataset, untuk melihat apakah label prediksi sesuai dengan label aslinya. Hasil pengamatan tertera pada tabel 6.

Tabel 6. Perbandingan Label Prediksi Dan Label Asli

\begin{tabular}{lcc}
\hline \multicolumn{1}{c}{ Twitter } & Label Prediksi & $\begin{array}{c}\text { Label } \\
\text { Asli }\end{array}$ \\
\hline Males banget mau berangkat nyoblos ke tps rawan corona & Negatif & Negatif \\
Dukung seluruh proses pilkada, tetap jaga jarak terapkan 3M & Positif & Positif \\
Mari kita sukseskan pilkada 2020 & Positif & Positif \\
\hline
\end{tabular}

Pada tabel 6 model diuji dengan kalimat baru, hasil label prediksi pada kalimat baru sesuai dengan label aslinya. Namun, beberapa kalimat baru berlabel positif justru diklasifikasikan ke dalam sentimen negatif. Kesalahan klasifikasi tersebut dapat disebabkan oleh kalimat yang mengandung makna ambigu atau makna tersirat, penggunaan bahasa informal, ejaan tidak konsisten dan terdapat kemiripan kata dalam data training dan data testing [17].

\section{KESIMPULAN}

Hasil yang diperoleh dari penelitian analisis sentimen pilkada di tengah pandemi mendapatkan akurasi tertinggi sebesar 90\% dengan 4-layer convolutional dan 100 epoch. Akurasi dari keempat layer meningkat seiring bertambahnya jumlah epoch yang diterapkan. Dari epoch 50, 75 sampai 100 mengalami kenaikan akurasi berkisar antara 2-4\% dari variasi epoch sebelumnya. Hasil uji klasifikasi kalimat baru berhasil memberikan label prediksi sesuai dengan label aslinya. Namun terdapat beberapa kesalahan klasifikasi yang disebabkan oleh beberapa faktor, diantaranya terdapat kata dengan makna ambigu atau makna tersirat, penggunaan bahasa informal, ejaan tidak konsisten serta terdapat kemiripan kata dalam data training dan data testing. Penelitian kedepan disarankan menambahkan dataset dan menggabungkan beberapa metode lain seperti LSTM untuk meningkatkan akurasi.

\section{DAFTAR PUSTAKA}

[1] M. Rudiyanto and R. Kasanova, "Dampak Covid-19 Terhadap Implementasi Pendidikan Karakter Impact of Covid-19 on The Implementation of Character Education," Jurmal Pendidikan dan Teknologi 
Indonesia (JPTI)., vol. 1, no. 5, pp. 209-213, 2021, doi: https://doi.org/10.52436/1.jpti.43.

[2] S. C. Rizki and Y. A. Hilman, "Menakar Perbedaan Opini Dalam Agenda Pelaksanaan Kontestasi Pilkada Serentak Di Tengah Covid-19," J. Ilm. Muqoddimah, vol. 4, no. 2, pp. 143-155, 2020, doi: http://dx.doi.org/10.31604/jim.v4i2.2020.143-155.

[3] L. Zhang, S. Wang, and B. Liu, "Deep learning for sentiment analysis: A survey," Wiley Interdiscip. Rev. Data Min. Knowl. Discov., 2018, vol. 8, no. 4, pp. 1-25, doi: 10.1002/widm.1253.

[4] A. U. Rehman, A. K. Malik, B. Raza, and W. Ali, "A Hybrid CNN-LSTM Model for Improving Accuracy of Movie Reviews Sentiment Analysis,” Multimed. Tools Appl., vol. 78, no. 18, pp. 2659726613, 2019, doi: 10.1007/s11042-019-07788-7.

[5] D. W. Otter, J. R. Medina, and J. K. Kalita, "A Survey of the Usages of Deep Learning for Natural Language Processing," IEEE Trans. Neural Networks Learn. Syst., vol. 32, no. 2, pp. 604-624, 2021, doi: 10.1109/TNNLS.2020.2979670.

[6] A. Rajput, "Natural Language Processing , Sentiment Analysis and Clinical Analytics," 2019, https://www.researchgate.net/publication/330871275_Natural_Language_Processing_Sentiment_Analysi s_and_Clinical_Analytics/citations, (accessed Apr. 10, 2021)

[7] H. Cui, Y. Lin, and T. Utsuro, "Sentiment Analysis of Tweets by CNN utilizing Tweets with Emoji as Training Data," Proceedings of KDD (Wisdom'18), 2018, no. 4,pp. 1-8.

[8] Z. Guan, L. Chen, W. Zhao, Y. Zheng, S. Tan, and D. Cai, "Weakly-supervised deep learning for customer review sentiment classification,” IJCAI Int. Jt. Conf. Artif. Intell. 2016, pp. 3719-3725.

[9] S. Poria, E. Cambria, D. Hazarika, and P. Vij, "A deeper look into sarcastic tweets using deep convolutional neural networks," COLING 2016 - 26th Int. Conf. Comput. Linguist. Proc. COLING 2016 Tech. Pap.,2016, pp. 1601-1612.

[10] M. Rhanoui, M. Mikram, S. Yousfi, and S. Barzali, "A CNN-BiLSTM Model for Document-Level Sentiment Analysis," Mach. Learn. Knowl. Extr., vol. 1, no. 3, pp. 832-847, 2019, doi: 10.3390/make1030048.

[11] S. Sharma, "Epoch vs Batch Size vs Iterations," 2017. https://towardsdatascience.com/epoch-vsiterations-vs-batch-size-4dfb9c7ce9c9 (accessed Apr. 15, 2021)

[12] D. Wang et al., "Modulation Format Recognition and OSNR Estimation Using CNN-Based Deep Learning," IEEE Photonics Technol. Lett., vol. 29, no. 19, pp. 1667-1670, 2017, doi: 10.1109/LPT.2017.2742553.

[13] M. Khader, A. Awajan, and G. Al-Naymat, "The impact of natural language preprocessing on big data sentiment analysis," Int. Arab J. Inf. Technol., vol. 16, no. 3ASpecial Issue, pp. 506-513, 2019.

[14] Z. Jianqiang and G. Xiaolin, "Deep Convolution Neural Networks for Twitter Sentiment Analysis," IEEE Access, vol. 3536, no. c, 2017, doi: 10.1109/ACCESS.2017.2776930.

[15] R. Rahutomo, A. Budiarto, K. Purwandari, A. S. Perbangsa, T. W. Cenggoro, and B. Pardamean, "Tenyear compilation of \#savekpk twitter dataset," Proc. 2020 Int. Conf. Inf. Manag. Technol. ICIMTech 2020, pp. 185-190, doi: 10.1109/ICIMTech50083.2020.9211246.

[16] S. Alam and N. Yao, "The impact of preprocessing steps on the accuracy of machine learning algorithms in sentiment analysis," Comput. Math. Organ. Theory, vol. 25, no. 3, pp. 319-335, 2019, doi: 10.1007/s10588-018-9266-8.

[17] D. A. N. Taradhita and I. K. G. D. Putra, "Hate speech classification in Indonesian language tweets by using convolutional neural network," J. ICT Res. Appl., vol. 14, no. 3, pp. 225-239, 2021, doi: 10.5614/itbj.ict.res.appl.2021.14.3.2.

[18] W. Y. Chong, B. Selvaretnam, and L. K. Soon, "Natural Language Processing for Sentiment Analysis: An Exploratory Analysis on Tweets," Proc. - 2014 4th Int. Conf. Artif. Intell. with Appl. Eng. Technol. ICAIET 2014, pp. 212-217, 2014, doi: 10.1109/ICAIET.2014.43.

[19] M. K. Sohrabi and F. Hemmatian, "An efficient preprocessing method for supervised sentiment analysis by converting sentences to numerical vectors: a twitter case study," Multimed. Tools Appl., 2019, doi: 10.1007/s11042-019-7586-4.

[20] A. Bayhaqy, S. Sfenrianto, K. Nainggolan, and E. R. Kaburuan, "Sentiment Analysis about E-Commerce from Tweets Using Decision Tree, K-Nearest Neighbor, and Naïve Bayes," 2018 Int. Conf. Orange Technol. ICOT, 2018, pp. 1-6, doi: 10.1109/ICOT.2018.8705796.

[21] S. Anastasia and I. Budi, "Twitter sentiment analysis of online transportation service providers," 2016 Int. Conference Adv. Comput. Sci. Inf. Syst. ICACSIS, 2016, pp. 359-365.

[22] T. B. Rohman, D. D. Purwanto, and J. Santoso, "Sentiment Analysis Terhadap Review Rumah Makan di Surabaya Memanfaatkan Algoritma Random Forest," Prosiding Seminar Nasional Teknologi Informasi \& Aplikasinya, 2018, pp. 7-11.

[23] L. xia Luo, "Network text sentiment analysis method combining LDA text representation and GRU- 
CNN," Pers. Ubiquitous Comput., vol. 23, no. 3-4, pp. 405-412, 2019, doi: 10.1007/s00779-018-11839.

[24] A. Pambudi and S. Suprapto, "Effect of Sentence Length in Sentiment Analysis Using Support Vector Machine and Convolutional Neural Network Method," IJCCS (Indonesian J. Comput. Cybern. Syst., vol. 15, no. 1, p. 21, 2021, doi: 10.22146/ijccs.61627.

[25] J. Chen, S. Yan, and K. C. Wong, "Verbal aggression detection on Twitter comments: convolutional neural network for short-text sentiment analysis," Neural Comput. Appl., vol. 32, no. 15, pp. 1080910818, 2020, doi: 10.1007/s00521-018-3442-0.

[26] N. Purnama, P. K. Negara, and S. Primakara, "Deteksi Masker Pencegahan Covid19 Menggunakan Convolutional Neural,” J. RESTI (Rekayasa Sist. dan Teknol. Informasi), vol. 1, no. 10, pp. 576-583, 2021.

[27] W. Supriyanti and D. A. Anggoro, "Classification of Pandavas Figure in Shadow Puppet Images using Convolutional Neural Networks," Khazanah Inform. J. Ilmu Komput. dan Inform., vol. 7, no. 1, 2021, doi: https://doi.org/10.23917/khif.v7i1.12484. 